\title{
RECENT LEGISLATION AFFECTING CLOSE CORPORATIONS
}

\author{
F. Hodge O'NeAL*
}

INTRODUCTON

Pioneer writers on close corporations ${ }^{1}$ lamented the fact that corporation statutes laid down, without differentiation, the same rules for publicly-held and close corporations. ${ }^{2}$ They pointed out that the two are utterly different in their nature and in their methods of operation and that concepts and rules suited to the governance of the former are often ill-adapted to the latter. Accordingly, they suggested separate legislation for close corporations--either a completely new statute specially drafted for one-man, family, and other close corporations, ${ }^{3}$ or a statute based upon English legislation providing for "private companies."

In spite of the vigor and skill with which these suggestions were presented, however, no jurisdiction in this country has enacted a comprehensive statute setting up separate rules and regulations for close corporations. As a matter of fact, the term "close corporation" is not used at all in corporation statutes. A close corporation is still formed under the same general incorporation laws as a publicly-held corporation, is taxed on the same basis, and in general must conform to the same requirements.

Nevertheless, most modern corporation statutes, especially those which have been enacted or extensively revised since World War II, give an increased flexibility to the corporate form and, to a considerable extent, permit a molding of the corporate device to the needs of closely-held enterprises. Further, in a number of instances, statutory provisions, albeit of rather limited scope, have been enacted with the

* A.B. 1938, LL.B. I940, Louisiana State University; J.S.D. 1949, Yale University; S.J.D. I954, Harvard University. Professor of Law, Vanderbilt University; Visiting Professor of Law, New York University (1957-58). Author, Close Corporations: LaW aND Practice (1958); co-author [with Kurt F. Pantzer], The Drafting of Corporate Charters and By-Laws (195I).

IThe term "close corporation" has been defined in various ways-as a corporation with a relatively small number of shareholders, as a corporation in which ownership and management are substantially identical, and as a corporation whose shares are not traded on an exchange or an over-the-counter market. One-man companies and family corporations are examples of close corporations, but many close corporations are not owned by one person or a single family.

'Weiner, Legislative Recognition of the Close Corporation, 27 MrcH. L. REv. 273 (I929); Winer, Proposing a New York "Close Corporation Law," 28 CoRnelL L.Q. 3I3 (I943). See also Israels, The Close Corporation and the Law, 33 CORNeLI L.Q. 488 (I948). "It would seem that an intelligent approach to the general problem of incorporation would require at least three types of general incorporation laws in each state: One for the single incorporator, another for the small concern, and a third for the extensive business setup, for purposes of mass production." Rutledge, Significant Trends in Modern Incorporation Stattites, 22 WASH. U.L.Q. 305, 339 (1937).

${ }^{3}$ Weiner, supra note 2 , at $3 \mathrm{I}_{4}, 335$.

"Weiner, supra note 2, at 282-84. The "private company" is defined as one which (a) limits membership to fifty, (b) restricts the right to transfer shares, and (c) prohibits any invitation to the public. See L.C.B. Gower, The Principles of Modern Company Law 13 (1954). 
primary objective of meeting one or more of the problems peculiar to close corporations; and although the provisions are not by their terms so limited in practical operation, they apply largely, if not exclusively, to close corporations." Mention should also be made of the new North Carolina Business Corporation Act, ${ }^{6}$ whose draftsmen, keenly aware of the peculiarities of close corporations, inserted numerous provisions designed to meet their special needs. ${ }^{7}$

This article discusses the provisions in modern corporation statutes which affect close corporations, emphasizing legislative changes made during the last twenty years or so. For this purpose, the legislation is grouped under the following headings: (I) statutes giving the corporate form greater flexibility by authorizing the use of optional charter clauses and special bylaw provisions; (2) statutes authorizing unanimity or high-vote requirements for shareholder and director action; (3) statutes permitting participants in a corporation to depart in various other respects from the traditional pattern of stock corporation management; (4) statutes relaxing the requirements of formal corporate meetings and of strict compliance with traditional corporate ritual; (5) statutes relating to problems of deadlock and dissolution; (6) miscellaneous statutory provisions peculiarly applicable to close corporations; and (7) legislation proposed but not yet enacted.

\section{I}

\section{Statutory Provisions Authorizing Optional Charter Clauses and Special Brzaw Provisions}

Most modern corporation statutes give a great deal of latitude-much more than is generally supposed - to the lawyer who wants to mold the corporate form to a

${ }^{5}$ The difficulty of defining the close corporation and drawing a sharp line between it and the publicly-held corporation seems to account, in part at least, for the failure to limit the application of some of the new statutes to close corporations. The New York Law Revision Commission, in reporting on section nine of the New York Stock Corporation Law, infra note 29, stated: "No satisfactory way of defining the genuine close corporation for purposes of a statute has been found. Economically, the dis tinction between a close corporation and any other is that in the close corporation management and ownership are substantially identical, but the only way in which it appeared to the commission that a definition could be embodied in a statute would be to limit the amendment to corporations having not more than a stated number of shareholders, or not more than a stated amount of capital. This would necessarily be arbitrary, might not provide an adequate answer to the cconomic problem, and would possibly permit a single shareholder by splitting up his shareholding to break up the arrangement at will unless the remaining shareholders or the corporation bought him out." N.Y. State Law Revision COMM'N, REPORT 386 (I948).

Lowndes, Taxing the Income of the Close Corporation, 18 Law \& Contemp. Pros. 558, 582 (x953), suggests (giving credit for this thought to Professor Elvin R. Latty) that it seems possible "to make a distinction between those corporations whose stock is available to the public through a recognized exchange, or in over the counter markets, and those whose stock does not appear in any recognized market, or cannot be purchased without the consent of the corporate associates."

'N.C. Gen. Stat. c. 55 (Supp. 1955). For another recent statute taking a fresh approach to the problems of close corporations, see P.R. LAws ANN. tit. 14, $\$$ ro2 (c) (Supp. 1957) (providing for special management arrangements in a corporation whose certificate of incorporation contains a provision stating that it shall not have more than a specified number of shareholders, the number specified not being greater than eleven).

'See Latty, The Close Corporation and the New North Carolina Business Corporation Act, 34 N.C. L. REv. 432 (1956); Latty, Powers, and Breckenridge, The Proposed North Carolina Business Corporation Act, 33 N.C.L. REv. 26, 45, 5I (1954). 
particular business situation. They prescribe general rules for the organization, internal operation, and management of corporations-rules which apply in the absence of a contrary arrangement among the participants; but by and large-though subject to important exceptions in some jurisdictions-they give the participants considerable freedom to regulate internal matters by either charter clause or bylaw provision or by shareholders' agreement.

Almost all the corporation statutes authorize the use of optional charter clauses and special bylaw provisions which supply the draftsman with varied and serviceable materials for setting up a structure suited to the business. ${ }^{8}$ Statutory support for such clauses and provisions differs widely among jurisdictions, but the trend has definitely been toward a broader and clearer authorization of the use of those which depart from orthodox patterns.

\section{A. Statutory Provisions Specifically Designating Optional Clauses and Special Provisions}

The number and nature of charter or bylaw clauses and provisions authorized by statutory provisions of this sort traverse a broad range. In many states, only two or three clauses and provisions, if any at all, are thus specified; and not uncommonly, these are not the ones that are most needed in close corporations. Nevertheless, among the clauses and provisions expressly designated in one or more jurisdictions are some which can be exceedingly serviceable-such as those granting, ${ }^{9}$ defining, ${ }^{10}$ or enlarging ${ }^{11}$ shareholders' pre-emptive rights to purchase new shares; ${ }^{12}$ those imposing restrictions on the transferability of stock; $;^{13}$ those requiring unanimity or a high vote for shareholder or director action ${ }^{14}$ or requiring a high quorum for shareholders' and directors' meetings; ${ }^{\mathbf{1 5}}$ those empowering a particular class or designated classes of shares or securities to elect all or a specified number or proportion of the directors; ${ }^{18}$ those empowering directors elected by the vote of a particular class or designated classes of shares or securities to elect all or specified officers; ${ }^{17}$ and those specifying that no shareholder shall own or vote more than an indicated percentage of the corporation's stock. ${ }^{18}$

\footnotetext{
- See generally O'Neal, Molding the Corporate Form to Particular Business Situations: Optional Charter Clauses, Io VAND. L. REv. I (1956).

${ }^{\circ}$ E.g., Cal. Corp. CODE $\$ 305$ (b); Pa. Stat. tit. I5, $\$ 2582-204$ (II) (I938).

${ }^{10}$ E.g., MD. ANN. CODE art. $23, \S 26$ (195I).

${ }^{21}$ E.g., La. Rev. Stat. \& I2-3 (B)(I) (1950).

21 The participants in a closely-held enterprise will often be interested in preserving or strengthening their pre-emptive rights, because maintenance of their proportionate voting power and their proportionate interest in corporate dividends and preservation of the bargained for divison of control may be of great concern to them.

${ }^{19}$ E.g., Kan. Gen. Stat. ANN. $\$$ I7-2803 (F) (1949); MD. AnN. Code art. 23, $\$ 4$ (7) (I95I); R.I. Gen. Laws Ann. c. II6, 7 (I938).

24 E.g., Del. Code ANn. tit. 8, \$ 102(b) (4) (I953); N.Y. Stock Corp. LAW \$ 9; W. VA. Code ANN. $\$ 3018$ (j) (1955).

${ }^{15}$ E.g., N.Y. Stock CoRP. LAw $\$ 9$; ORE. Rev. Stat. $\$$ 57.165, 57.200 (I953).

${ }^{20}$ E.g., LA. REv. Stat. \$ 12:34 (D) (1950).

${ }^{17}$ E.g., id. \& 12:35 (E).

${ }^{28}$ E.g., Kan. Gen. Stat. Ann. $\$ 17-2803$ (E) (1949).
} 


\section{B. Statutory Provisions Defining Applicable Rules in Absence of Other Charter or Bylaw Coverage}

Statutory provisions of this sort furnish support for a large number of charter clauses and bylaw provisions. An examination of almost any modern corporation statute will reveal numerous sections containing phrases which state that the regulations laid down in the sections are to apply only in the absence of contrary provisions in the charter or bylaws or which otherwise indicate that the subject mattter of the sections may be regulated in the charter or the bylaws. ${ }^{10}$ For example, the Illinois Corporation Act provides as follows for charter or bylaw increase in the number of directors required for a quorum or for director action: ${ }^{20}$

A majority of the board of directors shall constitute a quorum for the transaction of business unless a greater number is required by the articles of incorporation or the bylaws. The act of the majority of the directors present at a meeting at which a quorum is present shall be the act of the board of directors, unless the act of a greater number is required by the articles of incorporation or the by-laws.

C. Statutory Provisions Broadly Authorizing Any Lawful Clauses and Provisions

Perhaps most helpful of all in supporting charter clauses and bylaw provisions needed in close corporations are broadly-worded statutory provisions. At the beginning of this century, the corporation statutes of a number of states contained a section broadly authorizing the use of optional charter provisions. ${ }^{21}$ One of the purposes of such a section was to enable those entering close corporations as minority shareholders to protect themselves by insisting on appropriate safeguards against increases in capital stock, increases in the number of directors, consolidations, and other changes in the corporation's structure or management which might adversely affect their rights. ${ }^{22}$

The number of states with broad statutory authorization of optional charter clauses has steadily grown, until at the present time, the corporation statutes of the great majority, including all the more important commercial jurisdictions, contain such a section. The pertinent section in the Delaware statute, ${ }^{23}$ which has identical or quite similar counterparts in a number of jurisdictions, ${ }^{24}$ is perhaps typical. It states that the charter may contain:

${ }^{10}$ See, e.g., ILl. REv. STAT. c. 32, $\$ \$ 157.14$, I57.15, 157.24, 157.25, 157.26, I57.31, 157.33, 157.34, $157.37,157.38,157-40,157.43$ (1955).

${ }_{20}^{\circ}$ Id. $\$ 157.37$. (Emphasis added.)

${ }^{21}$ See, e.g., Ala. Gen. Acts 1903 , act $395, \$ 2$ (j); N.Y. Sess. Laws 1895, c. 672, $\S$ Io; N.C. Pub. Laws, 1901, c. 2, $\$ 8$ (7); Va. Acts of Assembly, Extra Session 1902-04, c. 170, at 437. The National Banking Act of 1864 also contained a provision of this kind. See Bullard v. Banks, 85 U.S. ( 18 Wall.) 589 (1874).

${ }_{22}^{2}$ See Ripin v. United States Woven Label Co., 205 N.Y. 442, 447-48, 98 N.E. 855, 856-57 (1912).

${ }^{23}$ Del. CODE ANN. tit. 8, § 102 (b) (r) (1953).

${ }^{24}$ See, e.g., Ark. Stat. \$ 64-10I (i) (I947); FlA. Stat. \$608.03 (1955); GA. Code Ann. \$ 22-1082 (h) (Supp. 1956); MD. ANN. Code art. 23, \$ 4 (b) (9) (I95I); N.J. Rev. STAT. \& 14: 2-3 (1937). N.Y. GEN. CORP. LAw $\S 13$ (2) provides that a corporation's certificate of incorporation may contain "any provision for the regulation of its business and the conduct of its affairs, and any limitations upon its powers, or upon the rights of its stockholders or upon the powers of its directors and members, which does not exempt them from the performance of any obligation of duty imposed by law." 
Any provision which the incorporators may choose to insert for the management of the business and for the conduct of the affairs of the corporation, and any provisions creating, defining, limiting and regulating the powers of the corporation, the directors and the stockholders, or any class of stockholders, or, in the case of a corporation which is to have no capital stock, of the members of such corporation; if such provisions are not contrary to the laws of this State.

Many corporation statutes also contain a section generally authorizing special provisions in the bylaws. The language of these sections is similar to that of some of the sections authorizing optional charter clauses. The Illinois statute, for instance, provides that the bylaws "may contain any provisions for the regulation and management of the affairs of the corporation not inconsistent with law or the articles of incorporation." ${ }^{25}$

Unfortunately, it is not entirely clear exactly what charter clauses and bylaw provisions are sanctioned by these broadly worded statutes. In spite of the expansive language in which these statutes are couched, courts have, on occasion, construed them narrowly and have invalidated unorthodox charter clauses or bylaw provisions on the ground that they are not authorized. ${ }^{26}$ Therefore, some authors have cautioned against reliance on these statutes. ${ }^{27}$ In view, however, of the general repudiation of the old "concession theory" of corporate existence as inconsistent with the facts of present-day corporate life and the acceptance of the idea that corporate charters and codes of bylaws are primarily contracts among the participants in the enterprises, courts are likely in the future to give a consistently broad and inclusive scope to these statutory authorizations.

\section{II}

\section{Statutory Provisions Authorizing High-Vote Requirements for Shareholder and Director Action}

Businessmen forming a close corporation often want a power to veto some or all corporate policies and decisions. In particular, those who are to have minority interests want protection against the broad powers normally vested in shareholders and directors to determine corporate policy and to make decisions by simple majority vote. This desired power frequently can be given by charter clauses or bylaw provisions requiring unanimity or concurrence of a high percentage of voting units for shareholder or director action. Similarly, that power can be given by high-quorum requirement for shareholder and director action: whenever high-quorum requirements exist, a shareholder can prevent shareholder action by refusing to attend shareholders' meetings and can prevent director action by keeping his representative-assuming he has one-away from directors' meetings. ${ }^{28}$

${ }^{25}$ Ill. Rev. Stat. c. 32, $\$ 157.25$ (1955). See also Mo. ReV. Stat. $\$ 351.290$ (I949).

${ }^{20}$ For a discussion of some of the cases interpreting or applying the general statutes, see O'Neal, supra note 8, at 5-19.

${ }^{27}$ See Henry W. Ballentine, Corporations $\$$ i6 (rev. ed. 1946); Henry W. Ballantine and Graham L. Sterling, Jr., California Corporattons laws $\$ 37$ (1949).

${ }^{28}$ The use of high-vote and high-quorum requirements to give shareholders a veto over corporate 
The statutes authorizing high-vote and high-quorum requirements in the charter or bylaws fall within the broader category of statutes authorizing optional charter clauses and special bylaw provisions, discussed in the preceding section. The serviceability of these requirements in molding the corporate form to the needs of a closely-held enterprise is so great, however, that perhaps attention should be particularly called to typical statutes supporting them.

Undoubtedly the best known of statutory provisions authorizing high-vote and high-quorum requirements is section nine of the New York Stock Corporation Law, enacted originally in 1948 and since amended several times. ${ }^{20}$ It expressly provides that the certificate of incorporation can set up high-quorum requirements for shareholders' meetings and for directors' meetings and can require unanimity or a high vote for shareholder or director action. Section nine was enacted on the recommendation of the New York Law Revision Commission to overcome difficulties created for the close corporation by the famous decision of the Court of Appeals of New York in Benintendi v. Kenton Hotel. ${ }^{30}$ There, the court held invalid bylaws requiring unanimity for shareholders' resolutions, the election of directors, and directors' resolutions. The reasoning of the court, viz., that the requirements violated statutory norms and that one of the bylaws-the last-was inconsistent with the stautory' scheme of corporation management, was broad enough to invalidate the requirements even had they been in the certificate of incorporation rather than in the bylaws. At the time of its passage, section nine was praised as the first important legislative recognition of the distinctive management needs of close corporations. ${ }^{31}$

Although section nine is the statutory provision most often discussed, most states, in fact, now have enacted similar legislation authorizing high-vote and high-quorum requirements for shareholder action, for director action, or for both. ${ }^{32}$ An illustrative statutory authorization of charter clauses requiring a high vote for shareholder action is the following widely-prevalent provision: ${ }^{33}$

Whenever, with respect to any action to be taken by the shareholders of a corporation, the articles of incorporation require the vote or concurrence of the holders of a greater proportion of the shares, or of any class or series thereof, than required by this Act with respect to such action, the provisions of the articles of incorporation shall control.

action is discussed in some detail in O'Neal, Giving Shareholders Power to Veto Corporate Decisions: Use of Special Charter and By-Law Provisions, 18 LAw \& Contemp. Prop. 45I (1953).

${ }^{20}$ N.Y. STOCK CoRp. LaW $\$ 9$.

${ }^{30} 294$ N.Y. II2, 6o N.E.2d 829 (1945).

${ }^{31}$ de Capriles and Reichardt, 1947-1948 Strvey of New York Law-Corporations, 23 N.Y.U.L.Q. REv. 747 (1948).

${ }^{33}$ The statutes are discussed in O'Neal, Giving Shareholders Power to Veto Corporate Decisions: Use of Special Charter and By-Law Provisions, 18 LAw \& CoNTEMP. Prob. 45I, 457-60 (195I).

${ }^{33}$ IIL. Rev. StaT. c. 32, \$157.146 (1955); Mo. Rev. Stat. $\$ 351.270$ (I949); Tex. Bus. Corp. Act, art. 9.08 (1956); VA. Code $\$$ 13.I-33 (Supp. 1956); Model Business Corporation Act $\$ 136$. Scc also N.C. Gen. Stat. $\$ 55-66$ (Supp. 1955); Ohio Rev. Code Ann. $\$ 1701.52$ (Page Supp. 1956). 
And modern corporation statutes commonly authorize charter clauses or bylaw provisions requiring a high vote for director action as well by stating that: ${ }^{34}$

The act of the majority of the directors present at a meeting at which a quorum is present shall be the act of the board of directors, unless the act of a greater number is required by this chapter, the articles of incorporation or the bylaws.

\section{III}

\section{Statutory Provisions Permitting Departure from Traditional Management Patierns}

The participants in a close corporation often want to depart from the traditional framework of corporation management and to work out among themselves the allocation of control of the business. Although they value the limitation of personal liability the corporate form furnishes, they may want to retain all the freedom of partners in determining who is to control the enterprise and how that control is to be exercised. As has often been noted, shareholders in a close corporation not uncommonly desire to be shareholders to the outside world, but partners among themselves.

The high-vote and high-quorum requirements discussed in the part immediately preceding are departures from the traditional control pattern. But that is only one of the approaches that can be taken to the task of providing the management pattern desired by the participants. ${ }^{35}$ Another approach is indicated through variations in the corporation's share structure in the way shares are allocated. In most jurisdictions, statutory provisions governing stock classification and charter clauses on stock and financial matters give the draftsman considerable leeway in this regard. $^{36}$ In preparing the stock and financial clauses, the draftsman is not restricted to bare recitals of specified items; he has a wide choice as to the content and wording of the clauses he uses. Thus, by classifying shares, using nonvoting shares or shares with limited voting rights, varying other rights and preferences of the different classes of shares, and carefully parceling out the various classes of shares, almost any desired distribution of control can be obtained.

A third approach that can be followed to effect the desired distribution of control in a close corporation is the use of so-called irrevocable proxies: some of the participants give proxies on some or all of their shares to other participants, empowering the latter to vote the shares for a specified period of time or on stated contingencies. The difficulty with this approach is that in many jurisdictions, there is doubt as to whether proxies for this purpose can be made irrevocable. In general, courts have applied the rules of agency to proxies; and, therefore, in the absence of statute, proxies are usually held to be revocable, unless they are coupled with an interest, and

\footnotetext{
${ }^{34}$ E.g., Ill. Rev. Stat. c. 32, § 157.37 (I955); Ohto Rev. Code Ann. $\$$ I701.62 (Page Supp. 1956); Wis. STAT. $\$$ I80.35 (r955); MODEL Business CoRporation ACT $\$ 37$.

${ }^{36}$ See Ballard, Arrangements for Participation in Corporate Management Under the Pennsylvania Business Corporation Law, 25 TEMP. L.Q. 13I (195I).

${ }^{30}$ See, e.g., N.Y. STOCK CoRp. LAW $\S \mathrm{Ir}$.
} 
this is so even though they are in express terms stated to be irrevocable. ${ }^{37}$ Further, the concept "coupled with an interest" has proved vague and unhelpful. The courts, on some occasions, have sustained irrevocable proxies in close corporations, ${ }^{38}$ and on other occasions, they have held the proxies to be revocable. ${ }^{39}$ On the whole, statutes dealing with proxies have done little definitely to settle the question of wheni.e., under what circumstances-and for how long a proxy can be made irrevocable. ${ }^{40}$

In 1953, New York enacted a statutory provision which represents an ambitious effort to draw a clear-cut line between revocable and irrevocable proxies. It provides that a proxy which is entitled "irrevocable proxy" and states that it is irrevocable is irrevocable when it is held by one of the following or his nominee:41

(a) a pledgee under a valid pledge;

(b) a person who has agreed to purchase the stock under an executory contract of sale;

(c) a creditor or creditors of the corporation, other than a banking corporation, who extend or continue credit to the corporation in consideration of the proxy if the proxy states that it was given in consideration of such extension or continuation of credit, the amount thereof, and the name of the person extending or continuing credit;

(d) a person who has contracted to perform services as an officer of the corporation, other than a banking corporation, if such a proxy is required by the contract of employment, as part of the consideration therefor, if the proxy states that it was given in consideration of such contract of employment, the name of the employee and the period of employment contracted for.

The statutory provision, however, goes on to remove the attribute of irrevocability as soon as the proxyholder ceases to need protection, by providing that the proxy ${ }^{42}$ becomes revocable after the pledge is redeemed, or the executory contract of sale is performed, or the debt of the corporation is paid, or the period of employment provided for in the contract of employment has terminated, and becomes revocable, in a case provided for in paragraph (c) or (d) of this section, at the end of the period, if any, specified therein as the period during which it is irrevocable, or three years after the date the proxy was given, whichever period is the lesser, unless the period of irrevocability is renewed from time to time by the execution of a new irrevocable proxy. . . .

Further, the statute states that a provision making a proxy irrevocable is not en-

${ }^{37}$ In re Chilson, 19 Del. Ch. 398, 168 Atl. 82, 85 (Ch. 1933); State ex rel. Breger v. Rusche, 219 Ind. 559, 39 N.E.2d 433 (1942); Axe, Corporate Proxies, 4I Mrcr. L. Rev. 225, 256 (1942).

${ }^{38}$ Sec, e.g., Smith v. San Francisco \& N. Pac. Ry., xi5 Cal. 584, 47 Pac. 582 (I897): Ecclestone v. Indialantic, Inc., 319 Mich. 248,29 N.W.2d 679 (1947); State ex rel. Evcrett Trust \& Savings Bank v. Pacific Waxed Paper Co., 22 Wash. 2d 844, 157 P.2d 707 (1945).

${ }^{39}$ See, e.g., Johnson v. Spartanburg County Fair Ass'n, 210 S.C. 56, 41 S.E.2d 599 (1947); Roberts v. Whitson, I88 S.W.2d 875 (Tex. Civ. App. 1945).

${ }^{10}$ Many statutes simply state that a proxy shall not be valid after a specified period of time, unless a longer period is provided for in the proxy. Sce, e.g., DeL. Code ANn. tit. 8, \$212 (1953) (three years, unless proxy provides for a longer period); Moder Business Corporation Act $\$$ 3I (elcven months, unless otherwise provided in the proxy). They do not indicate elearly whether a proxy can be made irrevocable. N.C. GEN. STAT. $\$ 55-68(\mathrm{~b})$ (Supp. I955) provides that "no proxy, whether or not coupled with an interest or otherwise irrevocable by law, shall be valid after yo ycars from the date of its execution."

${ }^{42}$ N.Y. Stock CoRp. Law $\$ 47-a$.

${ }^{42}$ Ibid. 
forceable against a purchaser of stock without actual notice of the provision, unless notice of the proxy and its irrevocability appears on the certificates representing the affected shares.

Unless a proxy complies fully with the terms of this statutory provision, it will be held to be revocable, ${ }^{43}$ despite the fact that under decisions in some other jurisdictions, the particular proxy might be classified as one coupled with an interest. In other words, the New York statutory provision is a two-edged sword-validating some irrevocable proxies, but invalidating others.

Perhaps the most popular approach to the problem of distributing control in close corporations is through a shareholders' agreement. No attempt will be made here to enumerate and discuss the numerous considerations that may influence the decision of a court passing on the validity and enforceability of a typical shareholders' control agreement. Suffice it to say, a high percentage of such agreements contain provisions which are of doubtful validity under the judicial precedents.

The first legislative step to bolster shareholders' agreements and to draw a clear line between valid and invalid agreements was taken in the new North Carolina Business Corporation Act, which contains, among other things, the following provisions: ${ }^{44}$

I. An otherwise valid contract between two or more shareholders that the shares held by them shall be voted as a unit for the election of directors shall, if in writing and signed by the parties, be valid and enforceable as between the parties, but for not longer than ten years from the date of its execution.

2. Except in corporations whose shares are generally traded in the markets, no written agreement to which all the shareholders of a corporation have actually assented, whether embodied in the charter or bylaws or in any side agreement in writing and signed by all the parties, whether it relates to the management of the corporation's business or division of its profits or to any other phase of its affairs, shall be invalid between the parties on the ground that it is an attempt by the parties to treat the corporation as if it were a partnership or to arrange the parties' relationships in a manner that would be appropriate only between partners.

3. An agreement between all or less than all of the shareholders, whether solely between themselves or between one or more of them and a party who is not a shareholder, is not invalid as between the parties on the ground that it so relates to the conduct of the affairs of the corporation as to interfere with the discretion of the board of directors; but (with control properly comes responsibility) the making of such an agreement imposes upon the shareholders who are

${ }^{13}$ N.Y. GEN. CoRP. LAw $\$$ I9 (3) ("Every proxy shall be revocable at the pleasure of the person executing it, except as otherwise provided in section forty-seven-a of the stock corporation law."); In re Norton \& Schneider, Inc., 137 N.Y.S.2d 269 (Sup. Ct. 1954) ("irrevocable proxy"' given by one shareholder to another to vote stock in an election of directors held invalid).

"N.C. Gen. Stat. \$ 55-73 (Supp. I955). See also F.R. IAws Ann. tit. I4, § I102 (c) (Supp. 1957) (providing for special management provisions in the certificate of incorporation). 
parties thereto the same liability for managerial acts that is imposed by other provisions of the statute on directors.

Many of the successful attacks on control arrangements departing from the orthodox pattern of corporation management have been based on the argument that such arrangements violate the statutory norm conferring on the board of directors power to manage corporate affairs. ${ }^{45}$ The North Carolina statute precludes that ground of attack. In addition to the third provision above, the statute contains a section expressly stating that the norm of director-control shall be subject to modifying provisions in the charter, bylaws, or shareholders' agreements, which reads in part as follows: $:^{46}$

Subject to the provisions of the charter, the by-laws or agreements between the shareholders otherwise lawful, the business and affairs of a corporation shall be managed by a board of directors.

The section goes on to provide, however, that no limitation upon the authority which the directors would have had in the absence of the limitation is effective against persons without actual knowledge of it."

\section{IV}

Statutory Provisions Relaxing Requirements of Strict Observance of Corporate Formalities

Corporate rituals and the traditional formalities of corporate operation are often not observed in close corporations. Further, as shareholders and directors are usually the same people, it is not uncommon for the participants to fail to differentiate between what they do as shareholders and what they do as directors. Bylaw requirements are quite often flouted; and, indeed, in some parts of the country, many small close corporations do not have bylaws or even minutes books. There may be a fragmentary file of corporate minutes, but that file will frequently be limited to copies of a few resolutions, such as those required by banks for the opening of checking accounts and those required for the passage of title to real property.

According to traditional corporation doctrine, neither shareholders nor directors can act except at duly called meetings. ${ }^{48}$ The courts, however, have repeatedly relaxed the traditional rule in order to sustain informal action taken by participants in close corporations. For instance, they have held that whenever the affairs of a corporation are customarily carried on through informal conferences, decisions reached by all the directors and shareholders at an informal conference bind the

${ }^{45}$ See, e.g., Benintendi v. Kenton Hotel, Inc., 294 N.Y. I12, 60 N.E.2d 829 (1945); Manson v. Curtis, 223 N.Y. $3^{13}$, 119 N.E. 559 (1918).

${ }^{\circ}$ N.C. GeN. Stat. \$55-24(a).

"Id. $\$ 55-24$ (b).

${ }^{28}$ Henky W. Balinantine, Corporations $\$ \$ 44$, I70 (rev. ed. 1946). Notice of a special directors' meeting must be given to a minority director, even in a close corporation. Lyeetce v. Green River Gorge, Inc., 2r Wash.2d 859, r53 P.2d 873 (1944). 
corporation. ${ }^{49}$ Nevertheless, the rule requiring formal shareholders' and directors' meetings poses a serious risk to the validity of action informally taken in a close corporation.

In response to persistent demands from practicing lawyers and organizers of closely-held enterprises, the legislatures are gradually relaxing the traditional requirements of formal corporate meetings. Some modern corporation statutes permit both shareholders and directors to act informally and without a meeting by signing a written consent..$^{50}$ Under these statutes, however, unanimity is necessary; all the shareholders or directors, as the case may be, must sign for the written consent to be effective. ${ }^{51}$ Other statutes expressly permit the shareholders to act by written consent, but do not contain authorization for the directors to act in that way, ${ }^{52}$ thus implying that the directors cannot act informally. ${ }^{53}$

Legislative recognition of the informality of corporate meetings is also reflected in a section contained in a number of the new corporation statutes-e.g., the Virginia $^{54}$ and Texas statutes ${ }^{55}$-which states that notice of a directors' meeting may be waived after the meeting. This type of statutory provision affords a method for untangling some of the legal snarls that may result from the failure to hold proper meetings.

The new North Carolina Business Corporation Act may well set a pattern for future legislation. It contains elaborate provisions validating informal action by shareholders and directors, provisions avowedly drafted with the needs of the close corporation in mind. Since it may furnish the guide for draftsmen of other states on the subject of informal corporate action, its pertinent provisions are set forth here in full.

Section 55-29 of the Act provides:

Informal or irregular action by directors or committee.-(a) Action taken by a majority of the directors or members of a committee without a meeting is nevertheless board or committee action if:

49 Brainard v. De La Montanya, I8 Cal.2d 502, 5II, 1I6 P.2d 66 (194I); First Nat'l Bank v. Frazier, 143 Ore. 662, I9 P.2d I09I (I933); Miller v. South Hills Lumber \& Supply Co., 334 Pa. 293, 6 A.2d 92 (1939); National Bank v. Puget Sound Biscuit Co., 61 Wash. 192. 112 Pac. 265 (1910). See also Latty, A Conceptualistic Tangle and the One- or Two-Man Corporation, 34 N.C.L. REv. 471 , 475 (1956).

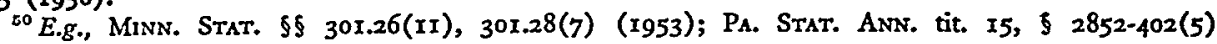
(Supp. 1956); Wis. STAT. \$ I80.91 (1955).

${ }_{51}$ The Ohio statute permits informal action by shareholders or directors, but authorizes "contrary" provisions in the articles or the regulations. OHro Rev. Code ANN. 170r.54 (Page Supp. 1956). The view has been expressed that the draftsmen of the statute, in referring to contrary provisions, had in mind provisions limiting shareholder and director action to action taken as a group at a formal meeting, and that they did not intend to permit the participants to provide in the articles or the regulations for action without a meeting upon the written approval of less than all of the shareholders or directors. See Dampeer, Genteral Corporation Law and Non-Profit Corporation Law, r6 Oнпо ST. L.J. 446, 480 (1956).

${ }^{5}$ E.g., Del. Code ANn. tit. 8, \$228 (x953); Modez Business Corporation Act \$ 138 .

"ss In jurisdictions in which the board cannot act by written consent, inconvenience to the whole board can sometimes be avoided by setting up an executive committee with authority to act for the board. Many corporation statutes contain a provision expressly authorizing creation of an executive board.

54 VA. CODE ANN. § I3.I-27 (Supp. 1956).

${ }^{8 E}$ TEX. Bus. Corp. ACT art. 9.09 (1956). 
(I) Written consent to the action in question is signed by all the directors or members of the committee, as the case may be, and filed with the minutes of the proceedings of the board or committee, whether done before or after the action so taken, or if

(2) All the shareholders know of the action in question and make no prompt objection thereto, or if

(3) The directors or committee members are accustomed to take informal action and this custom is known to all the shareholders and if all the directors or committee members, as the case may be, know of the action in question and no director or committce member makes prompt objection thereto.

(b) If a meeting of directors otherwise valid is held without proper call or notice, action taken at such a meeting otherwise valid is deemed ratified by a director who did not attend unless promptly after having knowledge of the action taken and of the impropriety in question he files with the secretary or assistant secretary of the corporation his written objection to the holding of the meeting or to any specific action so taken.

Section $55^{-6} 3$ of the Act provides:

Irregular meetings; action without meetings.-(a) The transaction of any meeting of shareholders, however called and with whatever notice, if any, are as valid as though had at a meeting duly held after regular call and notice, if:

(I) All the shareholders entitled to vote are present in person or by proxy and no objection to holding the meeting is made by any shareholder, or if,

(2) A quorum is present either in person or by proxy and no objection to holding the meeting is made by anyone so present, and if, either before or after the meeting, each of the persons entitled to vote, not present in person or by proxy, signs a written waiver of notice, or a consent to the holding of the meeting, or an approval of the action taken as shown by the minutes thereof. All such waivers, consents, or approvals shall be filed with the corporate records or made a part of the minutes of the meeting.

(b) The absence from the minutes of any indication that a shareholder objected to holding the meeting shall prima facie establish that no such objection was made.

(c) Any action which, under any provisions of this chaptèr, may be taken at a meeting of the shareholders, may be taken without a meeting if consent in writing, setting forth the action so taken, shall be signed by all of the persons who would be entitled to vote upon such action at a meeting and filed with the secretary of the corporation as part of the corporate records. Such consent shall have the same force and effect as a unanimous vote of shareholders, and may be stated as such in any certificate or document filed with the Secretary of State under this chapter.

$\because: \cdots:$ : :

Statutory Pröisions Relating to Problems ó Deadlock and Dissolution

Ä. Statutory Provisions Permitting Special Contractual Arrangements for Corporate Dissolution

Dissenșion among the shareholders falls with a heavy impact in a close corporation. A large part of the assets of some or all of the shareholders may be tied up in the company, and salaries received from employment by the company may furnish their principal livelihood. Not uncommonly, each of the shareholders is guaranteed membership on the board of directors and a particular office by a shareholders' agree- 
ment. As the shareholders are active in the business, they are in constant contact with each. Because of this intimacy, once dissatisfaction or distrust has developed, friction is likely to continue to grow.

In the close corporation, the relationship between the participants, like that among partners, is one which requires close cooperation and a high degree of good faith and mutual respect; but, when these conditions are absent, a participant does not have a partner's power to dissolve the business unit and get out. ${ }^{56}$ At the same time, the "way out" which is open to a shareholder in a publicly-held corporation, too, is not available to a participant in a close corporation. In a publicly-held corporation, a shareholder who is dissatified with the way in which the corporation is being operated can sell his shares at no great financial loss; but shares in a close corporation cannot be so easily disposed of. Anything less than a controlling interest in a close corporation does not have a ready market; and, if there is dissension in the corporation, a minority interest is likely to appear even less inviting to a prospective purchaser. Further, if there are restrictions on the transferability of shares, as is often the case, an irritated and obstinate associate is in a position to prevent the sale of the shares.

Whenever a shareholder in a close corporation wants to get out but cannot dispose of his shares without heavy financial loss, there often develops a state of affairs which is sometimes referred to as a "stalemate." 57 A dissatisfied shareholder's service may be necessary for the efficient operation of the business, or he may be frozen into the directorate and into an officership by a shareholders' agreement or other control arrangement. But in exasperation, he may consistently refuse to cooperate with his associates; in fact, he may do whatever he can to obstruct the operation of the corporation's affairs. The strife among the participants not infrequently results in incessant litigation and perhaps even in physical violence. ${ }^{58}$ This state of affairs, of course, harms the enterprise and results in serious losses to all shareholders.

But perhaps even more serious, "deadlocks" frequently occur among the shareholders and in the directorates of close corporations. The distribution of voting shares in close corporations is often such that an eventual impasse is possible or even probable. Such, for example, may be the case where the shares are equally divided

"A A partner may bring about the dissolution of the firm at any time. See UNIForm PartNershrp Act $\$ \S 3 \mathrm{I}(\mathrm{I})(\mathrm{b})$ (dissolution without violation of the partnership agreement by "the express will of any partner when no definite or particular undertaking is specified"), $\$ 3 \mathrm{I}(2)$ (dissolution in contravention of the agreement by the express will of any partner at any time). See also $i d$. $\$ 32$, providing that on application by or for a partner, "the court shall decree a dissolution whenever: (a) A partner has been dcelared a lunatic in any judicial proceeding or is shown to be of unsound mind, (b) A partner becomes in any other way incapable of performing his part of the partnership contract, (c) A partner has been guilty of such conduct as tends to affect prejudicially the carrying on of the business, (d) A partner wilfully or persistently commits a breach of the partnership agreement, or otherwise so conducts himself in matters relating to the partnership business that it is not reasonably practicable to carry on the business in partnership with him, (e) The business of the partnership can only be carried on at a loss, (f) Other circumstances render a dissolution equitable."

${ }^{77}$ See Israels, The Sacted Cow of Corporate Existence: Problems of Deadlock and Dissolution, I9 U. Ch. L. Rev. 778,78 r (1952).

${ }^{68}$ See, e.g., Stott Realty Co. v. Orloff, $26 z$ Mich. 375,247 N.W. 698 (I933); Nashville Packet Co. v. Neville, I44 Tenn. 698,235 S.W. 64 (rg2r). 
between two shareholders or groups of shareholders. Again, wherever directorates have an even number of members-not an uncommon occurrence-even divisions among the directors may well arise. Further, those who are to hold minority interests in closely-held enterprises, in an effort to protect themselves against the power normally vested in shareholders and directors to determine corporate policy and to make decisions by simple majority vote, often bargain for and obtain a veto over corporate policies and decisions. The granting of veto powers to some or all of the shareholders, of course, also greatly enhances the risk of corporate paralysis. In the colorful language of a Virginia court, these veto arrangements enable a recalcitrant shareholder or director to "embalm his corporation and hold it helpless ... in a state of suspended animation."

It may be advisable, therefore, in some close corporations, to set up special provisions for dissolution in the charter or bylaws or in a shareholders' agreement. Each shareholder might be given the power, similar to that of a partner, to obtain the dissolution of the concern at will, or if he first offers his shares to the other shareholders at a predetermined price and they do not purchase. Or provision might be made for compulsory dissolution of the corporation on the occurrence of specified events-e.g., the death or disability of any shareholder or of a particular shareholder, or the failure of the corporation to pay dividends in a specified amount for a named period of time. Another provision that might be useful in a shareholders' agreement is one binding all the shareholders to vote their shares for dissolution if a deadlock develops among the shareholders or directors and persists for a stated period of time, or if the terms of the directors expire and for a designated time the shareholders are unable to elect new directors.

On the other hand, provisions might also be included to make dissolution more difficult than it would otherwise be. For instance, a unanimous vote of the shareholders might be required for dissolution to protect minority shareholders against the possibility of a freeze-out in which majority shareholders would obtain the dissolution of the corporation and then take the business and its assets into another company in which the minority shareholders would have no interest.

There is serious doubt whether special dissolution arrangements will be given effect in jurisdictions where statutes fixing the shareholder vote and spelling out procedures for dissolution are couched in language that may be interpreted as mandatory. In the few instances in which a special dissolution provision has been challenged, however, it has been sustained by the courts. Thus, a Georgia court sustained a contract by which a shareholder promised to vote his stock for dissolution in consideration of another shareholder's undertaking to reimburse the promissor if the amount the promissor received from the liquidation was less than the sum he originally paid for his shares. ${ }^{60}$ And an agreement among the two shareholders of

${ }^{80}$ Kaplan v. Block, 183 Va. 327, 3r S.E.2d 893, 896-97 (I944).

${ }^{\circ 0}$ Wolf v. Arant, 88 Ga. App. 568, 77 S.E.2d xi6 (1953). See also Simonson v. Helburn, 97 N.Y.S.2d 406 (Sup. Cr. x950). But of. Flanagan v. Flanagan, 273 App. Div. 918, 77 N.Y.S.2d 682 (2d Dep't 1948), aff'd mem., 298 N.Y. 787, 83 N.E.2d 473 (1948). 
a corporation prohibiting either from bringing about the dissolution of the corporation except in ways specified in the agreement was given effect by a Massachusetts court, even though a statute provided that a corporation or its members might file for dissolution under circumstances different from those set forth in the agreement. ${ }^{61}$

The new North Carolina Business Corporation Act is designed to dispel any doubt about the validity of contractual arrangements for dissolution. That statute authorizes judicial liquidation of a corporation in an action by one of its shareholders whenever it is established that all of the shareholders ${ }^{62}$

... are parties to, or are transferees or susbcribers of shares with actual notice of a written agreement, whether embodied in the charter or separate therefrom, entitling the complaining shareholder to liquidation or dissolution of the corporation at will or upon the occurrence of some event which has subsequently occurred.

Query, however, whether this statute authorizes a court to enforce an agreement making dissolution more difficult to accomplish than it would otherwise be, and to refuse dissolution, otherwise called for, on the ground that it would be contrary to the agreement among the participants.

Some of the statutory materials authorizing unanimity or high-vote requirements for shareholder and director action ${ }^{83}$ would probably support charter clauses or special bylaw provisions giving shareholders a veto over decisions to dissolve by requiring unanimity for dissolution. Further, Iowa has a statute which states. specifically that a corporation may be dissolved "in accordance with the provisions of its articles"; ${ }^{64}$ and Massachusetts has one which provides that the agreement of association may contain a provision for the corporation's voluntary dissolution. ${ }^{65}$

\section{B. Dissolution-on-Deadlock Statutory Provisions}

Many jurisdictions, including practically all the more important commercial and industrial states, have statutory provisions specifically authorizing corporate dissolution in situations of deadlock in director or shareholder voting. There is considerable variation among these jurisdictions in the statutory language and some differences in the kinds of deadlock situations covered. The statutes discussed in the following paragraphs perhaps illustrate most of the variations.

The New York statute ${ }^{66}$ authorizes dissolution in the following situations:

${ }^{\circ 2}$ Leventhal v. Atlantic Finance Corp., 316 Mass. 194, 55 N.E.2d 20 (1944).

e2 N.C. GEN. Stat. \& 55-125(3) (Supp. 1955).

${ }^{\circ 3}$ See supra 345-47.

os Iowa CODE $\$ 491.23$ (1954). As statutory provisions setting a particular sharcholder vote for dissolution are designed to protect the shareholders, rather than the public generally, a strong argument can be made that even without specific statutory authorization, the shareholders can waive, limit, or contract away their rights under those statutes. See Annot., 154 A.L.R. 269, 270 (1945). For 2 discussion of New York statutes relating to dissolution and of the possibility of restricting the statutory right of the holders of a majority of the shares to seck a voluntary dissolution, see Note, I SYRAcuse L. REv. 489 (1950).

${ }^{\circ 5}$ Mass. ANN. Laws c. 156, § 6(h) (1948).

${ }^{80}$ N.Y. GEN. CORP. LAw $\$$ ro3. See generally on deadlock-dissolution problems in New York, Comment, 50 Colum. L. Rev. roo (1950); Note, 27 N.Y.U.L. Rev. 300 (1952); Burstein, The Dissolution of Closed Corporations, 123 N.Y.L.J. 1464, 1484, 1504 (April 26-28, 1950). 
I. A corporation has an even number of directors who are equally divided respecting the management of its affairs.

2. The votes of a corporation's stockholders are so divided that they cannot elect a board of directors.

3. A corporation's certificate of incorporation requires a vote for director action greater than otherwise would be required by law, and the directors are divided respecting the management of the corporation's affairs in such a way that the requisite number of votes for action by the board of directors cannot be obtained; or a corporation's certificate of incorporation requires a stockholder vote for election of directors greater than otherwise would be required by law, and the votes of the stockholders are so divided that the requisite number of votes for election of directors cannot be obtained.

An important restriction on a court's right to dissolve under the New York statute is that it must appear that the dissolution will be beneficial to the stockholders and not injurious to the public. ${ }^{67}$ This requirement has been applied by the Court of Appeals to deny dissolution of a deadlocked corporation if it is operating profitably. ${ }^{68}$

The deadlock statute in a number of states provides for dissolution whenever it appears that ${ }^{69}$

... the directors are deadlocked in the management of corporate affairs and the shareholders are unable to break the deadlock, and that irreparable injury to the corporation is being suffered or is threatened by reason thereof.

The Illinois statute authorizes dissolution on that ground or on the ground, which was added to the statute in $195 \mathrm{I}$, that ${ }^{70}$

... the shareholders are deadlocked in voting power, and have failed, for a period which includes at least two consecutive annual meeting dates, to elect successors to directors whose term has expired or would have expired upon the election of their successors.

This ground for dissolution, in that it propounds a standard that is definite and yet gives the participants a reasonable time to settle their differences, affords a sensible and workable basis for dissolution, and it is encouraging to note this ground is gaining widespread acceptance. ${ }^{71}$

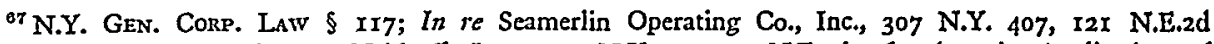
392 (1954); In re Radom \& Neidorff, Inc., 307 N.Y. I, II9 N.E.2d 563 (1954); Application of Cantelmo, 275 App. Div. 23I, 88 N.Y.S.2d 604 (Ist Dep't 1949) (dissolution will not be granted as beneficial to stockholders where petitioner is seeking to oust other stockholder from the business); In re Norton \& Schneider, Inc., 137 N.Y.S.2d 269 (Sup. Ct. 1954) (court recognized that its refusal to dissolve meant that the corporation would have to function for an indefinite time with a holdover board because the shares were evenly divided and could not elect a new board, but it denied dissolution because there had been no showing that dissolution would benefit the shareholders).

${ }^{88}$ In re Radom \& Neidorff, Inc., 307 N.Y. I, II9 N.E.2d 563 (1954).

${ }^{08}$ E.g., Ill. Rev. Stat. c. 32, \$ 157.86 (a) (I) (I955); Mo. Rev. Stat. \$ 351.485 (1949); PA. Stat. tit. 15, \$ 2852-1107 (A) (4) (I938). Cf. Ind. ANn. Stat. \$25-242 (6) (1948) (the "shareholders or directors are deadlocked in the management of the corporate affairs, and the corporation is suffering or is about to suffer, irreparable injury by reason thereof").

${ }^{70}$ ILL. Rev. Stat. c. 32, \$ 557.86 (a) (2) (1955).

${ }^{71}$ Among the corporation statutes which contain a provision of this kind are: N.C. GEN. STAT. $\$ 55-$ 125 (a) (2) (Supp. I955); Wis. STat. $\$$ I80.77I (I) (a) (4) (1955). 
The California statute ${ }^{72}$ authorizes a court to entertain proceedings for the involuntary winding-up or dissolution of a corporation on any one of a number of grounds including the following:

I. The corporation has an even number of directors who are equally divided and cannot agree as to the management of its affairs, so that its business cannot longer be conducted to advantage or so that there is danger that its property or business will be impaired and lost.

2. The holders of the voting shares of the corporation are so divided into fractions that they cannot agree upon or elect a board of directors consisting of an uneven number.

3. There is internal dissension and two or more factions of shareholders in the corporation are so deadlocked that its business cannot longer be conducted with advantage to its shareholders.

Most of the deadlock statutory provisions clearly cover a situation in which a board with an even number of members divides equally and the shareholders cannot resolve the deadlock by election of a new board because the shares are evenly divided between two shareholders or two factions. Some of the statutes, however, apparently do not authorize the dissolution of a corporation which is deadlocked because the charter or bylaws of the corporation require unanimity or a high vote director or shareholder action and no faction can get the necessary vote; or, if they do authorize dissolution in such a situation, they do not permit a shareholder with relative small holdings to bring the petition. Thus, the Massachusetts statute ${ }^{73}$ does not permit a petition for involuntary dissolution to be filed on the basis of deadlock except by the holder or holders of not less than forty per cent of the corporation's stock, and then only if the votes of the corporation's board of directors and of its stockholders

... are equally divided on a question affecting the general management of the affairs of the corporation, or if the votes of its stockholders are equally divided in the election of directors, and there appears to be no way of reaching an agreement and breaking such deadlock.

On the other hand, some statutes are broad enough unequivocally to authorize dissolution where deadlock is brought about through the operation of high-vote or high-quorum requirements. ${ }^{74}$

C. Statutory Provisions Allowing a "Buy-Out" As Substitute for Dissolution

A few states have statutory provisions which empower majority shareholders, whenever dissatisfied minority shareholders bring a suit for the dissolution or winding up of the corporation, to avoid the dissolution by purchasing the shares of the dissatisfied shareholders at their fair value, as determined by a prescribed pro-

${ }^{72}$ CAL. CORP. Code $\$ 465$ I (b-d).

${ }^{73}$ Mass. ANn. Laws c. 155, $\$ 50$ (1948). See also N.J. Rev. Stat. $\$$ 14:13-15 (Supp. 1955).

${ }^{74}$ Minn. Stat. $\$ 301.49$ (4) (1953); N.Y. Gen. Corp. Law $\$ 103$. 
cedure. $^{75}$ This buy-out provision is desirable, because it permits majority shareholders to preserve the enterprise as a going business and, at the same time, guarantees a dissatisfied shareholder a fair price for his holdings.

Perhaps dissolution-on-deadlock statutory provisions could be improved by specifying that whenever a deadlock results from the operation of high-vote or highquorum requirements for shareholder and director action, rather than from an equal division of shareholders and directors, majority shareholders will have an option to purchase the minority shareholders' interest at a price determined in a specified way. As a matter of fact, consideration might well be given to provisions empowering each shareholder or faction in a corporation deadlocked by an even division to set a value on a half-interest in the enterprise, which the opposing parties would then have to give for the offeror's interest or accept for their own interest.

\section{VI}

\section{- Miscellaneous Statutory Provisions Applicable to Close Corporations}

\section{A. Texas Statutory Provision Dealing With Restrictions on the Transferability of Shares}

Participants in a close corporation often want the power to choose their future business associates. That power is commonly given to them by placing restrictions on the transferability of the corporation's shares of stock. By far the most popular restrictions in this country are the so-called "first option," which gives the corporation or the other shareholders first refusal of the shares of a holder who decides to sell and sometimes an option to purchase the shares of a holder who dies or leaves the employment of the company; and buy-and-sell arrangements, which require the estate of a deceased shareholder to sell and the corporation or the surviving shareholders to buy the deceased's interest in the company.

As a general proposition, the courts, in the absence of statutory provisions to the contrary, sustain restrictions which they think are "reasonable" in the light of all the circumstances of the particular case, ${ }^{76}$ irrespective of whether the restrictions are in the charter, the bylaws, or a shareholders' agreement. With very few exceptions, the courts have upheld first options and buy-and-sell arrangements. Under the Uniform Stock Tranfer Act, ${ }^{77}$ however, a restriction will not be given effect, at least as to purchasers without knowledge of it, unless it is stated on the share certificates affected.

A section of the new Texas Business Corporation Act is unique, in that it attempts a legislative statement on the validity of share transfer restrictions. In general, the statutory provision follows the rules laid down by the judicial decisions and the Uniform Stock Transfer Act. It provides first that a corporation ${ }^{78}$

${ }^{76}$ Conn. Gen. Stat. $\$ 5228$ (1949); Cax. Corp. Code $\$ \S 4658$-59; W. VA. Code Ann. $\$ 3093$ (1955).

${ }^{70}$ See Annot., 2 A.L.R.2d 745 (1948); O'Neal, Restrictions on Transfer of Stock in Closely Held Corporations: Planning and Drafting, 65 HARv. L. REv. 773, 777-784 (1952).

77 UNIFORM STOCK TRANSFER ACT $\$ 15$.

${ }^{78}$ Tex. Bus. Corp. ACt art. 2.22 (1956). 
... may impose restrictions on the sale or other disposition of its shares and on the transfer thereof, which do not unreasonably restrain or prohibit transferability, if each such restriction is expressly set forth in the articles of incorporation or by-laws of the corporation and is copied at length on the face or so copied on the back and referred to on the face of each certificate representing shares. ...

It then goes on to state that in addition to any other restrictions which may reasonably be imposed on the transfer of its shares by any corporation under the above provision, the following restrictions may be imposed $:^{79}$

(r) Restrictions reasonably defining pre-emptive or prior rights of the corporation or its shareholders of record to purchase any of its shares offered for transfer.

(2) Restrictions reasonably defining rights and obligations of the holders of shares of any class, in connection with buy-and-sell agreements binding on all holders of shares of that class, so long as there are no more than twenty holders of record of such class.

(3) Restrictions reasonably defining rights of the corporation or of any other person or persons, granted as an option or options or refusal or refusals on any shares.

The following points about the Texas statute should be particularly noted. First, it limits the use of buy-and-sell agreements to classes of stock which are held by twenty persons or less. Query, whether this limitation is desirable as a matter of policy; the use of buy-and-sell agreements to restrict classes of stock which are widely-held may lead to complications, but whether a buy-and-sell agreement is to be used in any particular situation might well be left to the business judgment of the persons involved. Second, its wording raises some doubt whether restrictions other than buy-and-sell arrangements are valid if placed in a shareholders' agreement, rather than in the charter or bylaws. Third, it does not attempt to settle the question of whether "consent restraints"-i.e., restrictions requiring the approval of the directors or the shareholders for a transfer of shares-are "reasonable" and, thus, valid. Fourth, it does answer one question that has perhaps never been settled by the cases-namely, whether first options on shares may be granted to persons other than the corporation or its shareholders; the answer is in the affirmative.

B. Statutory Provisions Empowering Directors to Fix Their Own Compensation as Directors and Officers

One of the most difficult problems in a close corporation is to find a method of fixing executives' compensation which will not later be subject to attack. As majority shareholders in a close corporation are usually its controlling directors and principal officers, a disinterested quorum of directors to pass resolutions on executives' salaries often cannot be obtained.

In 1951, Wisconsin enacted what was then unique legislation designed to solve the problems involved in fixing the compensation of corporate officers and execu-

${ }^{70} \mathrm{Ibid}$. Subject to minor changes in capitalization and punctuation, the language which follows in the text is that of the statute. 
tive employees when those officers and employees constitute a majority of the board of directors. ${ }^{80}$ In brief, the directors are given the power to establish reasonable compensation for officers and employees, irrespective of any personal interest of the directors. In 1955 , a similar statutory provision was adopted in Ohio. ${ }^{81}$ The Wisconsin statute reads in full as follows:

Unless otherwise provided in the articles of incorporation or by-laws, the board of directors, by the affirmative vote of a majority of the directors then in office, and irrespective of any personal interest of any of its members, shall have authority to establish reasonable compensation of all directors for services to the corporation as directors, officers or otherwise, or to delegate such authority to an appropriate committee. The board of directors also shall have authority to provide for or to delegate authority to an appropriate committee to provide for reasonable pensions, disability or death benefits, and other benefits or payments, to directors, officers and employees and to their estates, families, dependents or beneficiaries on account of prior services rendered by such directors, officers and employees to the corporation.

Note that the statute clearly states that the compensation must be reasonable. The proponents of this legislation contend that while a shareholder can still bring a suit based on the claim that director-employees are engaging in self-dealing in fixing their own compensation, the result reached in the litigation will turn on the reasonableness of the director-employees' compensation, and not on a technical defect in the corporate action fixing the compensation. ${ }^{82}$ The second sentence in the Wisconsin statute was designed to answer any doubt of the power of the directors to grant reasonable benefits or additional compensation to executives or other employees based on their past services, or to grant pensions or allowances to the widows or dependents of executives or other employees.

\section{VII}

\section{Legislation Proposed But Not Enacted}

Perhaps a few words should be said about legislative proposals which have been advanced recently with problems of special importance to close corporations in mind, but which thus far have not been enacted. Two proposals have been made with a view to protecting minority shareholders against self-serving and selfish action by majority interests. A bill introduced in New Jersey a few years ago would have limited the discretion of the board of directors by requiring a declaration of dividends whenever the earned surplus of a corporation having one class of stock becomes "greater than ten times the par value of its capital stock issued and outstanding, or ten times the amount subscribed for and paid in on the capital stock of the company if the same be of no par value," unless holders of two-thirds of the shares

${ }^{80}$ Wis. STAT. \$ $180.3 \mathrm{Y}$ (1955).

${ }^{81}$ Ohro Rev. Code Ann. $\$ 1701.60$ (Page Supp. 1956).

${ }^{82}$ See comments of the draftsmen in the accompanying annotations. Ibid. See also Dampcer, supra note $5 \mathrm{I}$, at $48 \mathrm{x}$. 
consent to the withholding of dividends. ${ }^{83}$ This would have enabled minority shareholders who could muster the votes of over one-third of the shares to defeat schemes by majority interests designed to freeze-out the minority by withholding dividends indefinitely, while perhaps paying comfortable compensation to majority shareholders in officerships.

The new North Carolina Business Corporation Act, as originally proposed, contained a subsection, omitted in the statute as finally enacted, ${ }^{84}$ which afforded a remedy to minority shareholders if the controlling shareholders should try to dilute the proportionate interests of the minority by causing new shares to be issued at less than their value to themselves or their relatives or friends. ${ }^{85}$ Pre-emptive rights, even assuming that they have not been denied by special charter or bylaw provision, do not always protect minority shareholders against that possibility, because new shares may be issued, perhaps designedly, at a time when minority shareholders cannot finance their acquisition of new shares. The subsection omitted from the North Carolina statute provided expressly that a pre-emptive offer to a shareholder of his pro rata part of new shares or treasury shares would not deprive him of a cause of action based on the issuance of the shares at a price which unfairly diluted his holdings, if there was no ready and adequate market for the sale of his rights under the offer and if he notified the corporation in writing that he was financially unable to accept the offer and that he believed the offering price to be so low as unfairly to dilute his holding. The subsection went on to provide that in an action of this type, evidence tending to show prior efforts to induce the shareholder to sell his shares to directors, officers, or dominant shareholders of the corporation would put upon the defendant or defendants the burden of proving that the offering price was fair.

The proposal that would have perhaps the most significant effect of all on close corporations, were it to be adopted, is the one that would treat close corporations as partnerships for income tax purposes. Professor Charles L. B. Lowndes argues convincingly that in close corporations, the separate corporate entity should be disregarded and the shareholders taxed directly upon their distributive shares of the corporate income in the same way that the income of a partnership is taxed to the partners. ${ }^{86}$ Somewhat along these lines, the Internal Revenue Code of 1954 , at the time it was introduced, contained a-provision which would have permitted, subject

${ }^{83}$ S. 273 (1955), discussed in Note, 10 RuTGers L. REv. 723 (1956). An earlier New Jersey statute contained language which seemed to require dividend payments by the directors, but Stevens v. United States Steel Corp., 68 N.J. Eq. 373, 59 Atl. 905 (Ct. Err. \& App. 1905), imposed limiting conditions which rendered the provision ineffective, and it was later repealed. A number of states now have or have had legislation similar to the old New Jersey statute. See, e.g., N.M. STAT. ANN. c. 5I, $\$$ 3-I6 (I953); N.C. Gen. StaT. \$ 55-II5 (1950), abrogated by N.C. Gen. Stat. \$55-50(j) (Supp. r955).

84 S. $49, \S 55-46$ (h) (I955).

${ }^{85}$ For a discussion of freeze-outs of minority shareholders by the bad faith issuance of additional shares, sce Note, 35 N.C.L. Rev. 27 I (1957).

${ }^{80}$ Lowndes, supra note 5 , at 58r. Proposals to class small corporations as partnerships for income tax purposes were made as early as 1928 . See Weiner, supra note 2 , at $283-84$. 
to certain conditions and limitations, a close corporation to elect to be taxed as a partnership $;^{87}$ but that provision was eliminated in the conference committee. ${ }^{88}$

\section{ConcLusion}

Many, if not most, modern corporation statutes are sufficiently elastic in their provisions that informed lawyers can mold the corporate device to meet the principal needs of a closely-held enterprise, although careful planning and resourceful and imaginative drafting are essential to accomplish that objective. Further, a number of statutes of limited scope have tackled problems which are peculiar to, or at least most acute in, close corporations, and the prophecy can safely be made that there will be an even greater legislative recognition of close corporations problems in the future. ${ }^{89}$

This legislative recognition probably will not take the form of a separate statute laying down comprehensive regulations applicable solely to close corporations. Perhaps a separate statute would be undesirable, in that it would tend to discourage the expansion of close corporations into publicly-held ones. In any event, most members of the corporate bar seem to be opposed to a separate statute. Future developments in statutes affecting close corporations rather may well follow the innovations in the new North Carolina Business Corporation Act. Draftsmen charged with revising the corporation laws of other states should seriously study that imaginative and carefully-drafted legislation.

The taxation of close corporations on the same basis as partnerships would eliminate some of the tax-avoidance schemes now so widely prevalent and would permit many corporate decisions which are now based primarily on tax considerations to be made solely on the basis of business considerations. That change also might encourage the initiation and growth of small enterprises. Eventual modification of the tax laws to tax close corporations as partnerships is a distinct possibility.

All in all, the steady growth in the number of statutory provisions favorable to close corporations and the prospect of additional and perhaps more rapid developments in the future demonstrate that the labors of the pioneer writers, who pleaded so eloquently for legislative recognition of the distinctive needs of close corporations, have not been entirely in vain.

${ }^{81}$ Senate Committee on Finance, Internal Revente Code of 1954, S. Rep. No. $1622,83 \mathrm{~d}$ Cong., 2d Sess. x18-19, 452-58 (1954). See also Haddad, Organization and Operation of Corporations, 43 ILL. B.J. 547 (1955).

${ }_{88}$ Conference Committee, Internal Revenue Code of 1954, H.R. Rep. No. 2543, 83d Cong., 2d Sess. 72 (

"Incidentally, there are many signs of an increased judicial recognition of the special problems of close corporations. For judicial developments, see Scott, Developments in Corporate Latus, 12 Business LAWTER 438, 439-46 (1957). 